\title{
The Influence of Religiusity and Halal Label through Halal Awareness Purchase Decisions
}

\author{
Wisnu Mahendri ${ }^{1}$, Junianto Tjahjo Darsono ${ }^{2}$, Achmad Firdiansjah $^{3}$ \\ ${ }^{1}$ Management Department, Faculty of Economics and Business, Universitas Merdeka Malang, Indonesia \\ ${ }^{2,3}$ Faculty of Economics and Business, Universitas Merdeka Malang, Indonesia \\ wisnumahendri@gmail.com
}

\begin{abstract}
This study examines four variables namely religiosity, halal labels, halal awareness and purchasing decisions. The purpose of this study is to analyze and explain the effect of religiosity and halal labels on KFC product purchase decisions by testing halal awareness as intervening. The research respondents were KFC consumers in Jombang which were Muslim. A total of 133 respondents were sampled in this study. The analysis technique is descriptive and linear regression for confirmation on a structural equation model built by the researcher. The quantitative approach was chosen to explain the influence between research variables. Data collection using a questionnaire. The results of this study found that religiosity, halal labels and halal awareness had a positive impact on purchasing decisions for KFC products in Jombang. In previous studies, most religiosity variables and halal labels on purchasing decisions were examined without using intervention variables. This study includes an intervention variable, namely halal awareness to see its effect on purchasing decisions.
\end{abstract}

Keywords

religiosity, halal label; halal awareness, purchasing decisions

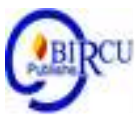

\section{Introduction}

Indonesia has a large market capacity for the world's halal industry, based on a report published by Thomson Reuters in State of The Global Islamic Economy 2016/2017 placing Indonesia at the first stage in terms of consumption of halal food at $\$ 154.9$ billion. Halal food demand in Indonesia is not accompanied by a number of halal food producers who have halal certificate. Some reports convey that the level of halal consciousness and the decision to purchase low halal food in Indonesian society. The Indonesian population is predominantly Muslim. Residents of Jombang 97\% Islamic religion, this makes the culture of Islam and students very felt in Jombang.

Consumers when buying halal food will also be influenced by how in their understanding of the Islamic religion that leads to their awareness to consume only halal food. Ambali Research \& Bakar (2014), the level of consumer awareness on halal food products is caused by several aspects and sources. The first aspect is religious beliefs. Religiusity is a religious passion for one who concerns symbols, beliefs, values and behaviors driven by spiritual constraints. The research of Fatmasari et al., (2014) explains that halal religiosity and labels have an influence on the decision of purchasing in Indonesia. In Research Nursanti \& Tielung (2014) Halal label have a positive influence on the purchase decision in the restaurant Solaria. Results of the study of Yasid et al, (2016) about the religiality, self-introduction and media exposure to halal consciousness gave the results that these variables have a positive and significant influence on the halal consciousness. Halal awareness is also influenced by the direct halal label in accordance with the research Ambali \& Bakar (2014). 
Clinical symptoms of schizophrenia are generally speech disorders such as the absence of connections between ideas (loose associations), sound associations (clang associations), behavioral disorders such as stupor or rowdy anxiety, doing the opposite of what is instructed (negativism), affective disorders such as shallowness of response emotions, excessive emotions, perception disorders such as hallucinations, mind disorders like delusions (Maramis, 2009).

Clinical symptoms that arise become one for the family and surrounding communities to support schizophrenia patients.

Based on research conducted in Aceh, Samosir, Central Java, NTB, and West Java, the results showed that schizophrenia is the most mental disorder that has experienced retention ( $90 \%$ of respondents). This is because schizophrenia is at risk of committing acts of violence resulting from symptoms, requiring long-term management because it is a chronic disorder and often recurs.

The act of restraint is an attempt at binding or physical restraint on people with mental disorders and aggressive / dangerous people in the community resulting in loss of freedom to access services that can help restore the function of people with mental disorders. Prolonged restraint affects physical disability, chronic physical illness due to infection, malnutrition, and dehydration which often results in permanent disability and death. Inclusion also makes it more difficult for people with mental disorders to integrate into society due to social, economic, spiritual and cultural disabilities (Kementerian Kesehatan, 2017). Then empowerment can also be interpreted as one of the solutions for those who experience powerlessness so that they participate in feeling the results of development that they have not fully felt, this is because development is actually considered as something that weakens the position of communities (Adiwijaya, 2018).

Aceh Mental Hospital is the only referral hospital (tertiary) in Aceh Province to treat people with mental disorders. The most common diagnosis for inpatients in Aceh Mental Hospital is schizophrenia. The average length of stay in 2018 is 59.76 days. According to the guidelines for minimum hospital service standards from the Ministry of Health, the length of stay (LOS) standard for people with mental disorders is $\leq 6$ weeks or 42 days (Aceh Mental Hospital, 2009) \& (Kementrian kesehatan RI, 2008).

Schizophrenia is classified into serious mental illness (SMI) because it is chronic. People with SMI have a higher risk of hospitalization and are associated with increased medical costs and use of health care resources. In United Kingdom, this disease reaches 3.4 million or $7.2 \%$ of total beds per day (Newman, 2018).

The main impact of the increase in the length of stay (LOS) for hospitals is the use of more resources, causing a decrease in hospital revenue, especially revenue derived from JKN-BPJS payments. This is due to JKN-BPJS using the Indonesia Case Base Groups (INA $\mathrm{CBGs)}$ system in determining package rates.

There is a discrepancy between researchers related to research results on halal food purchase decisions. Therefore, this research tries to bridge the existence of these gaps. External factors such as, religiusity, halal label and halal consciousness are assessed as variables affecting purchasing decisions. Based on the question, the authors feel the need to research on the influence of Religiusity and halal label to purchase decisions through halal awareness as a variable intervening in the product KFC in Jombang. 


\section{Review of Literatures}

The awareness of halal products is important for a Muslim. A Muslim who has awareness about their halal products not only think about labels or health only, but they will be loyal to halal products because they understand and mnegetahui about the prohibition and what they get when consuming products that are not kosher. Spiritual values and religiality will influence behavior and action and become the basis of behavior directly and ultimately impact the choice of food they consume. Religious beliefs are guidelines for determining what foods we consume because religion enforces some food restrictions, such as Islam that is forbidden to consume.

Halal labels and religious beliefs are of significance to the decision of food purchase in Indonesia (Fatmasari et al., 2014). Religiusity, self-introduction and exposure to media affects the halal consciousness of Muslim consumers will kosher food both partially and simultaneously (Yasid et al., 2016). Religious beliefs, media exposure, halal labels, health reasons and halal awareness. The findings of this study show that religious beliefs, media exposure and health reasons have significant effect on Halal awareness (Ambali \& Bakar, 2014). Halal awareness, halal certification, food quality and promotion are simultaneously significant effect on purchasing decision. But the halal consciousness variables have no partial significant effect on the purchase decision (Nursanti \& Tielung, 2014). Halal Label, halal awareness, product price and brand image are simultaneously significant effect on purchasing decision (Aspan et al., 2017).

\section{Research Methods}

The location of this research is done in Jombang district, especially in the outlet KFC Linggajati Plaza Jombang. KFC Jombang was chosen because in Jombang District licensing for food franchises from abroad is very restricted, because the district government Jombang keep the culture of Jombang as a city santri, then the administration of mambation to give operation permits in the franchise foreign food and large malls, because in the worry of the presence of foreign food franchises and large malls then will change the culture of KFC was the first franchise to operate in Jombang after several proposed operational permits. The data collection techniques in this study used the questionnaire.

The population in this study was based on researchers ' observations over the period of 15 Julis 2019 until 28 July 2019 was 975 people. The target population with Muslim criteria and once bought at least 2 times is 200 people. Sampling techniques in this study using the formula Slovin obtained the number of samples in this study were as many as 133 respondents. Methods for analyzing the influence of religiosity and halal labels on purchasing decisions through halal awareness using a descriptive analysis tool and the analysing of the path analysis.

\section{Discussion}

\subsection{Influence of Religiosity and Halal Labels on Halal Consciousness}

The overall consumption rate of Muslims in the world is estimated at US \$1.9 trillion, of which 89 percent of them or US $\$ 1.7$ trillion are used to consume food and beverage products. The consumption rate is expected to increase by 2 times more than US $\$ 3$ trillion in 2021 with the consumption of food and beverages amounting to US \$1.9 trillion (compound growth rate of 8.5 percent) (LATIF, n.d.). Indonesia has a great potential for the halal product market because it has a majority of Muslims, which is 207176162 people or 87 percent of 
the total population ("The Population census 2010-the population according to the Dianut Region and religion | Indonesia, "n.d.). This condition is supported by the opportunity of demand from non-Muslim consumers to halal products so it is possible to do the capitalization of halal products. (Rosalani, 2016) of the Indonesian Chamber of Commerce explained that in 2014, the market value of Halal products reached US \$2.3 trillion and the number was projected to increase to US \$3.7 trillion in 2019 (Julianto, n.d.). Nevertheless, Indonesia's halal food and beverage industry is still losing far from non-Muslim countries such as Australia and Brazil (LATIF, n.d.). In addition, there are still many outstanding products that have not been halal certified offered to Muslim consumers as a majority of the population. In 2011, only 36.73 percent of the 113515 registered products or only 41695 of food products, medicines, and cosmetics circulating in Indonesia have been certified halal.

There are several factors that affect the awareness of halal (awereness) from consumers who will further respect the demand for halal products (purchase intention). Some of these factors are: religiosity (religious believe), self-identity, and halal certification. Halal consciousness (awereness) is defined as the understanding of the product of a person from a consumer so as to make it careful in consumption of a product (Ishaq \& Prayoga, 2017). Religiusitas affect the halal consciousness. Based on the results of the research of people who have a higher religious level then the higher level of awareness in sorting halal food that will be consumed, as stated by (Hussaini, 1993) that the religiosity of a Muslim can affect the level of consciousness in the selection of halal food. Religiusitas is a guideline for Muslims in determining the food that will be consumed because in Islam there are some restrictions to not consume for example dog meat, pork and so forth.

The results of this research are in accordance with the research conducted by (Yasid et al., 2016) which states that religiosity significant effect on halal awareness on the purchase of halal food to the three-campus students in Yogyakarta namely Islamic University of Indonesia, State University of Yogyakarta and Sunan Kalijogo State Islamic University Yogyakarta

Halal label has significant effect on the halal consciousness, which means by the presence of halal label on KFC products impact on consumers who feel safe by buying products KFC because the halal label owned by KFC is a halal label issued by the indonesian ulama council. The indicator that has the highest contribution to the increase of consumer halal awareness is the assessment of the labels that are reflected from consumers who always pay attention to the value of the food they will consume. The halal label is a label listed in the product packaging and selling place stating that the food has passed the halal cheque from the local Indonesian ulama council. Referring to the Government Regulation number 69 article 10 and 9 of 1999, stating that any food producers or packaging food throughout Indonesia for trading is obliged to declare that the food is halal for Muslims and responsible for the correctness of the statement and must include halal information on the label. From the results of this research can be concluded that with the halal label in the product KFC can be used as a material consideration or reference that affects the level of halal consciousness when it will choose to consume a meal. The results of this study were consistent with previous research conducted by (Ambali \& Bakar, 2014) stating that the Halal logo positively affects the level of consciousness consuming halal food on Muslims.

\subsection{Influence of Religiusity and Halal Labels on Purchasing Decisions}

Religiosity significantly affect the purchasing decision, indicating that the low level of religiusidity of a person affects the purchase decision of KFC. The Islamic religious factor is indeed the main factor of a Muslim to buy halal food, but for a Muslim who has a good Islamic doctrine regarding halal and haram food, the influential religiuistas in determining the 
food to be purchased. Ideological consumers have a very strong belief in the teachings of Islam and believe that Islam is the most correct religion, this causes the influence of religiusity to the purchasing decision because the belief in Islam is absolute and has been converted since childhood. In the side of worship, the consumer is obedient in the conduct of Islamic Shari'a that has been taught in the pillars of Islam. Eating halal food is included in the teachings of Islamic sharia. So kosnumen choose to always buy food that is halal and see from the income of consumers who can afford to buy products KFC. The results of this study were in accordance with the study conducted by (Fatmasari et al., 2014) stating that religiosity have significant influence on the decision of food purchase in Indonesia. In another study conducted by (Muslichah, Abdulllah, \& Razak, 2014) stated that Religiusity has no significant effect on the purchase decision.

Halal labels have significant effect on purchasing decisions. Indicating that there is a halal label in KFC is very meaningful for consumers to convince them that KFC can be consumed by Islamic sharia without the label of halal consumers will hesitate to buy KFC products because they do not feel safe, clean and healthy. Because the main purpose of a halal label is to provide a sense of security, clean and healthy on every product that has a halal label Majelis Ulama Indonesia. This is in accordance with the research conducted by (Nursanti \& Tielung, 2014) which mentions that the halal label has significant effect on the purchase decision. Respondents already know about the halal label that is valid in Indonesia which is the halal label issued by The Indonesian Ulama Council and halal label owned by KFC provides assurance that the products offered by KFC are freed from materials that are banned in Islam.

\subsection{The Influence of Halal Consciousness on Purchasing Decisions}

Halal consciousness significantly affects purchasing decisions. It reflects that the respondent has extensive knowledge of Islam and makes the respondents wise in choosing halal food and avoiding unclean food. The level of halal consciousness of a good respondent is based on many respondents who have ever received education boarding school and Madrasah Diniyah. With the Islamic knowledge they have, the respondent will apply the behavior of Islam in life, one of which is to consume only halal food. Halal consciousness is the attitude of a Muslim in choosing the food that will be consumed, this attitude relies on the knowledge he has, both religious knowledge about halal haram mauapun general knowledge of food ingredients that are harmful to their bodies. The results of this research are as stated by (Hamdan, Issa, \& Abu, 2013) that the halal consciousness significantly affects the

purchasing decision. While the other research conducted by (Aspan et al., 2017) stated otherwise, that the purchase decision is not influenced by the halal consciousness.

\subsection{Influence of Religiustas and Halal Labels on Purchasing Decisions through the Halal Consciousness}

The halal awareness of the influence of religiusity and halal labels on purchasing decisions. This is because the respondents who are conscious of halal must have a good background of religious education, a vast knowledge of religion and a religious person in life. Increasing the awareness of halal in the community in Indonesia should be addressed by the food market actors to immediately have a halal label, because the community needs to guarantee that the food they consume halal. The guarantee can be obtained from the halal label issued by the indonesian ulama council. The halal Label issued by The Indonesian Ulama Council is increasingly trusted by the community because the Indonesian Ulemas Council in carrying out its duties not only focuses on the halal food that is examined but also to hygiene, food safety. So the halal label issued by the Indonesian Ulama Assembly is a 
kosher toyyib. Halal that is made possible by Islamic religion and thoyyib that is useful for the body and does not damage the body. Respondents tend feel confident in the halal label of Indonesian Ulama Council without the need to know in detail the materials used by KFC in processing food. Because in some opinion scholars are not required to know the ins and outs of a food sampe to the materials used, but is to be chopped to the opinions of other scholars who guarantee that the food is halal for him

\section{Conclusion}

Religiusitas and Halal labels have significant effect on the halal consciousness. Which means the better the religiosity of a Muslim and the halal label of the Indonesian Ulemas Council will further increase the halal consciousness of a Muslim. Religiusitas and Halal labels have significant effect on purchasing decisions. Which means that the better religiuistas owned by a person and a halal label owned by a brand will affect consumers to decide to buy products from the brand. Halal consciousness significantly affects purchasing decisions. Which means the respondent in selecting the purchased food feel the need to choose a food that is lawful to him and the greater the awareness of a Muslim to the importance of halal food, then he will only buy the halal certified from the Indonesian Ulama Council. Religiusitas and Halal labels affect the decision of purchasing through halal consciousness. This proves that the religiosity of a Muslim and halal labels owned by the food brand will affect the purchasing decision if the Muslims are aware of halal food needs for him. The biggest variable of influence is halal label.

\section{References}

Ahmad, N. A. B., Abaidah, T. N. B. T., \& Yahya, M. H. B. A. (2013). A Study on Halal Food Awareness among Muslim Customers in Klang Valley. Ministry of Social Affairs and Employment, 1(95), 120-121.

Alfian, I. (2017). Analisis Pengaruh Label Halal, Brand dan Harga terhadap Keputusan Pembelian di Kota Medan. At-Tawassuth.

Ali, M. (2016). Konsep Makanan Halal dalam Tinjauan Syariah dan Tanggung Jawab Produk atas Produsen Industri Halal. AHKAM: Jurnal Ilmu Syariah, 16(2), 291-306. https://doi.org/10.15408/ajis.v16i2.4459

Ambali, A. R., \& Bakar, A. N. (2014). People's Awareness on Halal Foods and Products: Potential Issues for Policy-makers. Procedia - Social and Behavioral Sciences, 121(September 2012), 3-25. https://doi.org/10.1016/j.sbspro.2014.01.1104

Arikunto, S. (2010). Prosedur Penelitian Ilmiah. In Rineka cipta, Jakarta.

Aspan, H., Sipayung, I. M., Muharrami, A. P., \& Ritonga, H. M. (2017). The Effect of Halal Label, Halal Awarness, Product Price, and Brand Image to the Purchasing Decision on Cosmetic Products (Case Study on Consumers of Sari Ayu Martha Tilaar in Binjai City). International Journal of Global Sustainability, 1(1), 55. https://doi.org/10.5296/ijgs.v1i1.12017

Aziz, Y. A., \& Chok, N. V. (2013). The Role of Halal Awareness, Halal Certification, and Marketing Components in Determining Halal Purchase Intention among Non-Muslims in Malaysia: A Structural Equation Modeling Approach. Journal of International Food and Agribusiness Marketing, 25(1), 1-23.

https://doi.org/10.1080/08974438.2013.723997 
Fatmasari, Sukesti, \& Budiman, M. (2014). the Influence Halal Label and Personal Religiousity on Purchase. International Journal of Business, Economics and Law, 4(1), 2012-2015.

Fatmawati, I., \& Pramintasari, T. R. (2013). Pengaruh Keyakinan Religius , Peran Sertifikasi Halal , Paparan Informasi , dan Alasan Kesehatan Terhadap Kesadaran Masyarakat Pada Produk Makanan Halal. Jurnal Manajemen Bisnis, 8(1), 734-766.

Ghozali, I. (2009). Aplikasi Multivariate Program SPSS. In Universitas Diponegoro, Semarang.

Ghozali, I. (2011). Aplikasi Analisis Multivariate dengan menggunakan SPSS. In Gramedia.

Hamdan, H., Issa, Z. M., \& Abu, N. (2013). Journal of Food Products Marketing Purchasing Decisions among Muslim Consumers of Processed Halal, (December 2013), 37-41. https://doi.org/10.1080/10454446.2013.724365

Hameeda, S., Gillani, B., Ijaz, F., Officer, A., Mahmood, M., \& Khan, S. (2016). Role of Islamic Financial Institutions in Promotion of Pakistan Halal Food Industry. 3(1), 2949.

Hasibuan, S. W., Nasution, Y., and Siregar, S.2019. The Effect of Health and Religious Beliefs on Consumer Consciousness of Using Halal Cosmetics. Budapest International Research and Critics Institute-Journal (BIRCI-Journal) (2): 239-249.

Huber, S., \& Huber, O. W. (2012). The Centrality of Religiosity Scale (CRS). Religions. https://doi.org/10.3390/rel3030710

Hussaini, M. M. (1993). Islamic Dietary Concepts \& Practices. In The Islamic Food \& Nutrition Council of America.

Ishaq, I., \& Prayoga, A. (2017). Kesadaran Halal dalam Minat Beli Produk Kue yang Belum Bersertifikat Halal. Prosiding Seminar Nasional Halal Awarness 2017, (July), 1-7. https://doi.org/10.13140/RG.2.2.30758.68162

Julianto, P. A. (n.d.). Permintaan Global Meningkat, Indonesia dan Malaysia Pacu Produk Halal. Retrieved March 7, 2020. https://money.kompas.com/read/2016/08/02/061716526/permintaan.global.meningkat.i ndonesia.dan.malaysia.pacu.produk.halal

Kelly, J. R., Stark, R., \& Glock, C. Y. (1968). American Piety: The Nature of Religious Commitment. Sociological Analysis. https://doi.org/10.2307/3710152

Kotler, P., \& Keller, K. L. (2009). Marketing management (13th ed.). In Prentice Hall.

Kotler, Philip, \& Armstrong, G. (2018). Kotler \&amp; Armstrong, Principles of Marketing | Pearson. In Pearson.

Latif, H. (n.d.). State of The Global Islamic Economy 2016/17 | Zawya MENA Edition. Retrieved March 7, 2020, from https://www.zawya.com/mena/en/ifgpublications/ifgRegister/280916063519J/

Martinelli, I., Harahap, A., and Zainuddin. Community Economic Development Prospect Based on Wakaf Funds. Budapest International Research and Critics Institute-Journal (BIRCI-Journal) (2): 409-423.

Muslichah, Abdulllah, H. R. binti, \& Razak, A. L. bi A. (2014). The Effect of Reliogiosity on Purchase Decision towards Halal Foods with Awareness as Intervening Variable. Malaysia Indonesia International Conference on Economics, Management and Accounting (MICEMA 2014).

Nursanti, W., \& Tielung, M. (2014). The Effect of Halal (permissible) Food Labeling on Islam Customer Purchase Decision in Solaria Restaurant Manado. Telematics and Informatics, 19(1), 27-40. https://doi.org/10.1177/1742766510373715

Patnoad, M. S. (2001). Food safety education in England: A Report from the Neha/Cieh Sabbatical Exchange Program. Journal of Environmental Health. 
Santoso, S. (2012). Buku Latihan SPSS Statistik Parametik. in PT Elex Media Komputindo Kelompok Gramedia. https://doi.org/10.1016/j.optcom.2006.06.037

Schiffman, L., \& Kanuk, L. L. (2008). Perilaku Konsumen. Jakarta: Indeks.

Sensus Penduduk 2010 - Penduduk Menurut Wilayah dan Agama yang Dianut | Indonesia. (n.d.). Retrieved March 7, 2020, from https://sp2010.bps.go.id/index.php/site/tabel?tid=321

Sugiyono. (2013). Metode Penelitian Pendidikan Pendekatan Kuantitaif, Kualitatif, dan R\&D. Bandung CV alfabeta. Metode Penelitian Pendidikan Pendekatan Kuantitaif, Kualitatif, Dan R\&D. https://doi.org/10.1007/s13398-014-0173-7.2

Sugiyono, P. D. Metode Penelitian Kuantitatif, Kualitatif,dan R\&D. , Alfabeta, cv. (2016).

Sungkar, I., \& Hashim, D. (2009). The Global Halal Food Market and Updates on Global Halal Standards (presentation slides). Proceedings of the 1st EAP Regional Agribusiness Trade and Investment Conference on Agro-Enterprise Without Borders, July 30-31, 2009, Holiday Inn, Atrium, Singapore.,1-27. Retrieved from http://siteresources.worldbank.org/Inteapregtoprurdev/Resources/IrfanSungkar.pdf

Yasid, Farhan, F., \& Andriansyah, Y. . (2016). Factors affecting Muslim students awareness of halal products in Yogyakarta, Indonesia. International Review of Management and Marketing, 6(4), 27-31. https://doi.org/10.1016/j.nimb.2009.08.009 ER

Yunos, R. M., Mahmood, C. F. C., \& Mansor, N. H. A. (2014). Understanding Mechanisms to Promote Halal Industry-The Stakeholders' Views. Procedia - Social and Behavioral Sciences, 130, 160-166. https://doi.org/10.1016/j.sbspro.2014.04.020. 